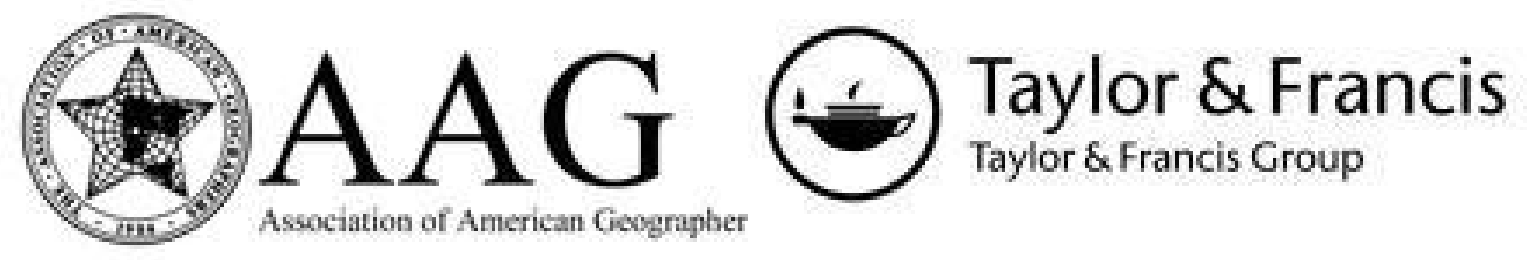

Geography in the Development of the Alaska Coal Deposits

Author(s): Alfred H. Brooks

Source: Annals of the Association of American Geographers, Vol. 1 (1911), pp. 85-94

Published by: Taylor \& Francis, Ltd. on behalf of the Association of American Geographers

Stable URL: http://www.jstor.org/stable/2560845

Accessed: 27-06-2016 10:44 UTC

Your use of the JSTOR archive indicates your acceptance of the Terms \& Conditions of Use, available at

http://about.jstor.org/terms

JSTOR is a not-for-profit service that helps scholars, researchers, and students discover, use, and build upon a wide range of content in a trusted digital archive. We use information technology and tools to increase productivity and facilitate new forms of scholarship. For more information about JSTOR, please contact support@jstor.org.

Association of American Geographers, Taylor \& Francis, Ltd. are collaborating with JSTOR to digitize, preserve and extend access to Annals of the Association of American Geographers 


\title{
GEOGRAPHY IN THE DEVELOPMENT OF THE ALASKA COAL DEPOSITS*
}

\author{
ALFRED H. BROOKS
}

CONTENTS

The commercial value of coal deposits...................... 85

The factors determining the economic value of coal.............. 86

The importance of geographic position....................... 86

The geologic elements in coal valuation...................... 88

The coal provinces of Alaska.............................. 89

Alaska coal and the Pacific Coast States...................... 90

Coal supplies in foreign countries.......................... 93

Alaska coal versus California oil........................... 93

Summary........................................... 94

The Commercial Value of Coal Deposits.-The ultimate importance to the human race of every ton of recoverable coal, no matter what its geographic position or geologic occurrence, admits of no argument. An evident corollary to this proposition is that every effort should be made to assure to mankind the maximum use of all the energy stored as coal. Though the recent literature on the value and proper utilization of our coal supply is voluminous, much of it is largely made up of sweeping generalizations, and there is an almost entire lack of searching analysis of the fundamental problems of economics which are involved.

Efficient recovery of mineral fuel and the most complete utilization of its contained energy obviously belong in the domain of technology, but the more fundamental problem as to whether it is to the best interests of mankind that a given coal field should be drawn upon now or at some time in the future, can only be answered by studying its geographic relations and, to a lesser extent, its geology. Obviously, this thesis involves the assumption that it is the function of the state to control the utilization of its natural resources. Assuming that governmental control is to be exercised, it is pertinent to inquire where a natural market for the product of a given coal field exists, or whether mankind would benefit by deferring its exploitation.

Probably a safe method of arriving at a conclusion as to the present importance of any given coal deposit is to determine its present monetary value, that is, the monetary value for development and not the value as a speculation for future development. The determination of such value involves the consideration of many factors, some of which

\footnotetext{
* Published by permission of the Director, U. S. Geological Survey.
} 
are only imperfectly understood. An attempt will be made, however, to discuss the principles which govern the economics of mineral fuel supply and to apply these to the Alaska coal fields.

The commercial valuation of any particular coal deposit is usually based on data which can be grouped under four headings, namely: (1) Quantity and quality, (2) cost of mining, (3) cost of transportation, (4) markets. Such a grouping admirably serves the purpose of the mining engineer whose object is to determine the present money value of any coal property or of an extensive field. All these factors will also enter into any broader discussion of the importance of any coal field or group of fields to mankind, but the economist, in contrast to the engineer, will make a somewhat different grouping and possibly arrive at a more fundamental analysis of the problem.

The Factors Determining the Economic Value of Coal.As I see it, the more important factors which determine the valuation to mankind of coal deposits fall into two general groups, which can be termed geographic and geologic. Of these the first is by far the more important. It includes the position of the coal on the earth's surface, hence its availability relative to population and industries, present and prospective, to other coal fields, and to other kinds of fuel. Given the market, almost any coal deposit can be mined, while without the market-either because of the competition of cheaper fuels or absence of population and industries-even a high-grade coal which is readily accessible can not be commercially developed.

Of the geologic factors overweight has usually been given to the chemical and physical properties of the coal. These items, while necessary for making a comparison of various coals in the same market, are in a general way becoming less important. The internal combustion engine has, for example, made available the energy of even the poorest class of lignites. It is not improbable that technical advances may soon break down the line between coking and non-coking coals. The following table is intended to set forth the factors controlling the value of coal deposits, using the term value in its broadest sense.

The Importance of Geographic Position.-The geographic position of the coal is evidently of first importance. Many coal deposits in the world, and notably some in Alaska, are so inaccessible that they can be regarded as having no present economic value, and in many instances it is difficult to forecast when such coals may become a part of the available supply. This is dependent on (1) population, (2) industries, and (3) exhaustion of other sources of fuel supply. The geographic relation of the coal deposit to population is evidently an all-important factor in its valuation and is involved in the question of its accessibility. The same holds true of its relation to industries, both present and prospective. It will also be evident that the position 
of the coal relative to other resources is an important factor in determining its value. This is notably true in relation to iron ore, but also holds to a lesser degree with respect to other metalliferous deposits. Any resources which attract industries and population must lead to railway construction and, all combined, will enhance the value of a coal field.

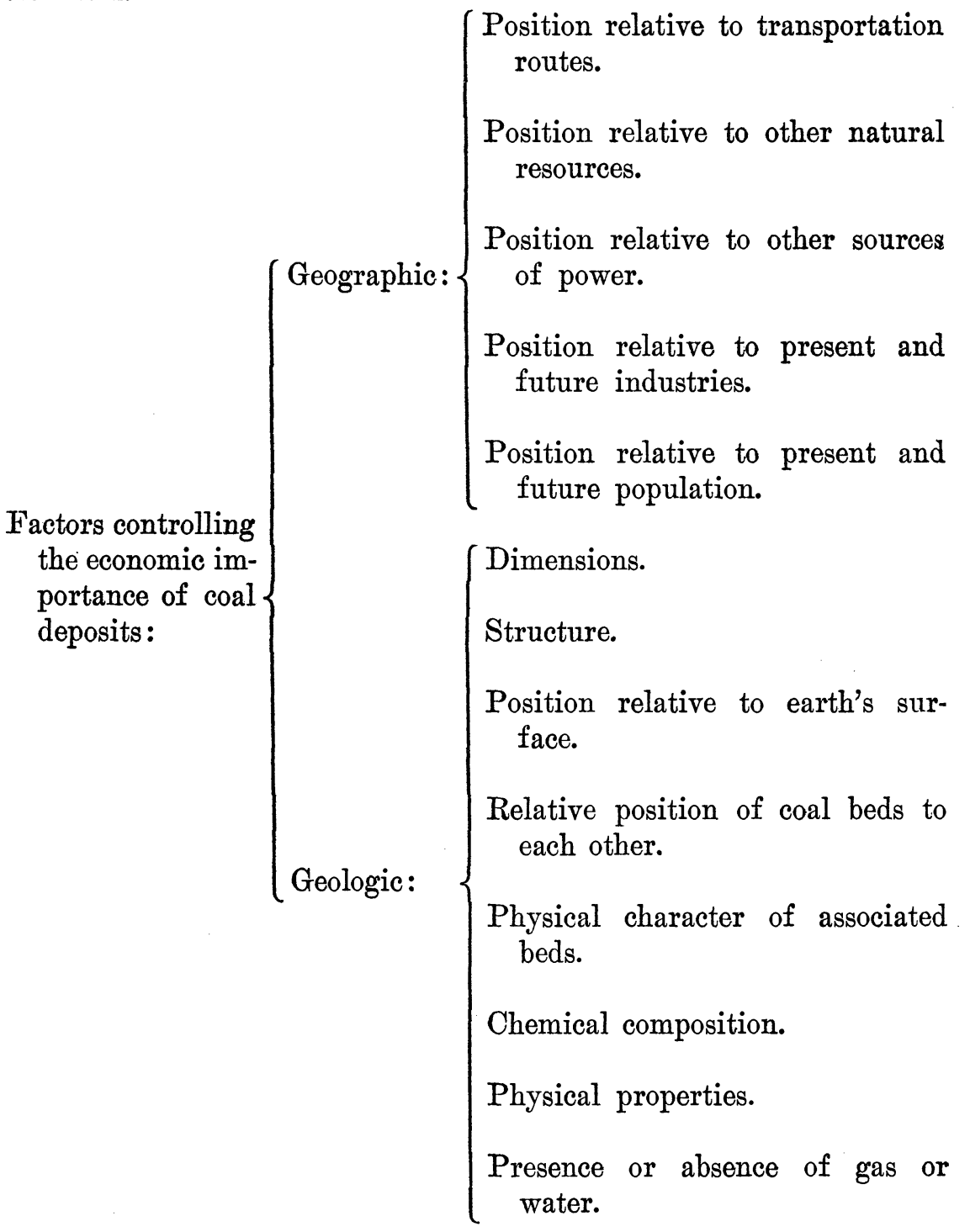

Of equal, if not greater, importance than those factors previously discussed is the position of the deposit relative to other sources of power. Under this heading should be considered competition with 
water powers, with other coal fields, and with other mineral fuels, such as gas and oil. To be entirely consistent, other possible sources of energy, such as the sun, the tides, and the wind should also be discussed, but this would lead into the realm of speculation rather than to tangible results.

The Geologic Elements in Coal Valuation.-The geologic elements in coal valuation will here be only briefly touched upon. These deal chiefly with (1) dimensions of the deposit, (2) fuel values, (3) geologic conditions which affect method and cost of extraction. The first of these needs no explanation. The second has to do with the chemical and physical composition of the coal, which determines its fuel value. It has already been pointed out that recent advances in technology indicate that the chemical and physical properties in the future will be of decreasing importance to the valuation of coal. Much has been written about the economic effect of the exhaustion of the Pennsylvania anthracite deposits. Such exhaustion is no more to be deplored than that of the equivalent in heat units of other varieties of coal in similar advantageous geographic position; indeed, the exhaustion of the Pennsylvania and West Virginia coking coals would be a far more serious matter. Anthracite is now used for no purpose for which bituminous coal could not be substituted. It is not impossible that eventually similar relations may hold between lignitic and bituminous coals.

Among the important factors affecting the cost of extraction is the depth of the coal beneath the surface. This is of almost equal importance with geographic position in determining the value of the coal. Coal can be mined under methods now employed, to depths of about 4,000 feet. It is possible that, when the more accessible coals are exhausted, means will be devised to mine coal at even greater depths. Here, again, the geographic factors which determine the market for the coal will also determine the depth to which it can be profitably mined. There are other geologic factors, such as position of beds, deformation, character of roof and floor, and presence or absence of gas and water, which greatly affect the cost of mining. Conditions may so enhance the cost of mining in any given field that the product can not compete with that of other fields where the conditions favor cheaper extraction. Here again, the geographic position may determine availability, since the above factors must be considered with reference to competition.

It will be evident from the above that, while the geologic factors may, and often do, control the present value of any individual property, the geographic factors dominate the economics of a coal field or of a group of fields. In other words, if there be a sufficient market, almost any coal deposit can be mined, while without market, no coal 
deposit is worth mining. The importance of the geographic factors is emphasized in the valuation of coal fields which are difficult of access. This involves the consideration of growth and movements of population and the development of new industries and new sources of energy, as well as possible routes and means of transportation.

The Coal Provinces of Alaska.-One measure of the relative importance of the Alaska coal fields is obtained by comparing the quantity of fuel with that of better-known regions. It has been estimated that Alaska contains probably 150,000 million tons of coal. ${ }^{1}$ This is about four and one-half per cent. of the total estimated tonnage of the United States and its possessions and a little less than fifteen per cent. of the coal in lands which are still in government ownership. It is about a third more than the original coal supply of the State of Pennsylvania.

In view of the fact that Alaska is almost continental in its dimensions and that the coal fields are very widely distributed within the Territory and that much of the coal is of a low grade, these broad comparisons are very misleading. It becomes necessary to qualify any statement in regard to total quantity by considering what part of this total supply is available for present use. For this purpose the Alaska coal fields can be conveniently divided into three economic provinces based on geography. The first is the Pacific slope, which comprises the mountainous area drained to the Pacific Ocean. This province as a whole is readily accessible and its resources can be considered an asset of the present generation. It contains about forty per cent. of the known coal resources of Alaska, besides valuable deposits of metals and considerable areas of arable land, all of which can be opened up by railways. (See Fig. 1.) Some of this coal is of high grade and located favorably for export.

The central region includes the area lying north of the coastal mountain basin and is drained to Bering Sea by the Yukon and Kuskokwin rivers. It includes about thirty-five per cent. of the known coal, besides important gold deposits and considerable arable land. To reach this region by railway from open ports on the Pacific will require four hundred to six hundred miles of railway. The coals are of a lignitic character and under no conditions which can now be foreseen could they be mined for export. The coals of these fields, therefore, have value only for local use-a value which is enhanced by the other mineral resources and by the relative scarcity of other fuel.

The third province comprises northern Alaska, draining into the Arctic Ocean. This includes about twenty-five per cent. of the known

\footnotetext{
${ }^{1}$ Brooks, Alfred H., Alaska coal and its utilization. Bull. U. S. Geol. Survey,
} No. 442, pp. 53-55, 1910. 
coal, much of which is of a high grade. This part of Alaska is almost entirely isolated, as it is too far from open ports on the Pacific to permit of railway connection, and its rivers are locked in ice for all but two months in the year. Most of this field is unexplored, and the stated estimate of tonnage is probably far below the actual tonnage. There is good reason to believe that its coal supply may exceed that of all the rest of Alaska but, whatever it may be, the coal has no value unless as an asset to future generations.

It appears, therefore, (1) that the Pacific slope coal is the most valuable of the Alaska coal supply to the present generation, for it can be exported, (2) that the coal of the central province has value only as local population and industries develop, and (3) that the coal of the Arctic slope will not be drawn upon until that future time when the more accessible coals of the world approach exhaustion.

The Pacific Slope Coal Fields of Alaska.-A discussion of the development of Alaska coal fields will, therefore, be concerned chiefly with those of the Pacific slope. These coals are the only ones in the Territory which are available for the growing population of the western side of the North American continent and are, therefore, of national as well as local importance.

The estimated reserves of the Pacific slope fields is 60,000 million tons, much of which can be readily made available by the construction of railways. This tonnage is about five per cent. of the total coal tonnage still in government ownership in the western states. These Alaska deposits include considerable high-grade steaming and coking coal, as well as a large quantity of lignite. The geologic occurrence of the high-grade coals of the Pacific slope of Alaska need not be presented in detail, for it will suffice to say that they are in many places not so unfavorable as to prevent exploitation.

The position of these coals relative to transportation is favorable. There are large quantities of lignitic, with some sub-bituminous coals, which are on or close to tidewater. The fields of high-grade coals can be reached from open ports on the Pacific by railways from thirty to two hundred miles in length. From the coastal terminals of these railways to Puget Sound ports the distance is about twelve to fourteen hundred statute miles and about two thousand miles to San Francisco.

Alaskra Coal and the Pacific Coast States.-These coals are therefore available for the use of the Pacific Coast States, with their growing population and industries. The five million people in this section are the natural customers for that surplus of Alaska's highgrade coals which can not be locally consumed, yet must be mined to warrant the establishment of the mining industry on a profitable scale. In other words, as Alaska now uses only about one hundred thousand tons of coal annually, an export trade must be established to warrant the large investments needed to open up the coal fields. 


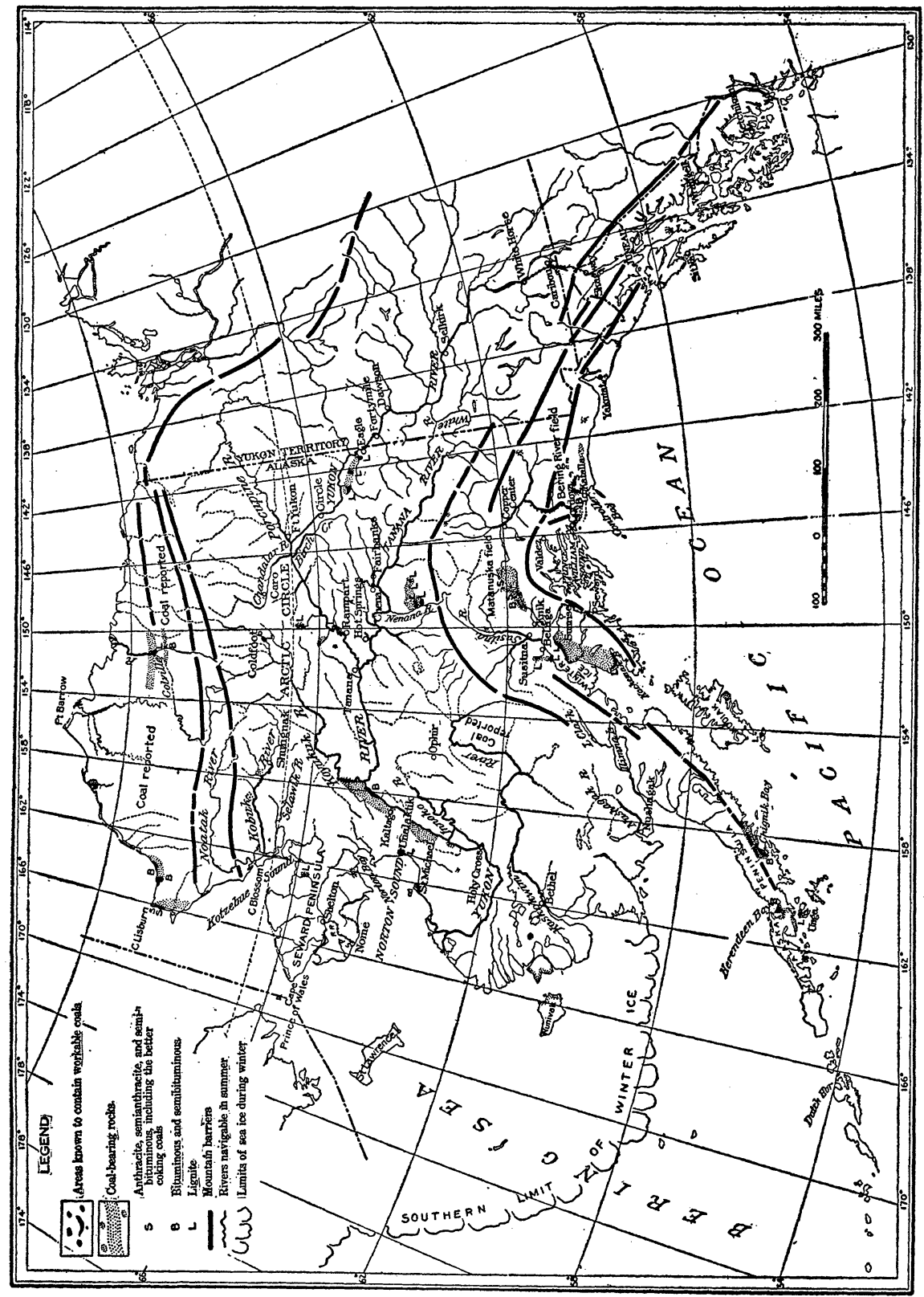

Fig. 1. 
At present, the industries most needing the Alaska coal are those of the Territory itself. These include primarily the whole transportation system, both railway and steamer, the mining industry and, to a lesser extent, the fisheries. Given cheap fuel, all these industries would rapidly develop, while without it they must lag. More important to the nation as a whole are the future needs of coal for the metallurgical industries of the Pacific seaboard. It has been estimated that this province now consumes over a million tons of raw and manufactured iron annually. Only a small part of this is supplied from local sources, the balance coming from the Eastern States, the Rocky Mountain States, and from foreign sources, including European countries and Asia. This long haul involves an economic waste of fuel and materially increases the cost to the consumer. With cheap coke there is no reason why the Pacific seaboard should not smelt its own iron ores. Other industrial uses need not be mentioned, but include manufactures as well as commerce.

The position of Alaska coal in relation to other natural resources has already been referred to. Metalliferous deposits are widely distributed in the Pacific slope region of Alaska. To develop them the coal is needed. Iron ore occurs in the Pacific Coast States and probably in Alaska, and could be used if coke were available. The opening of the coal fields will attract a population which, in turn, will lead to the development of Alaska's latent agricultural resources. It is by no means impossible that the world may draw on Alaska for a part of its meat supply, for the Territory includes the most extensive unoccupied grazing lands on the continent.

The position of the Aslaska coals in relation to other sources of power is the most important, as it involves the question of competition. Disregarding possible future sources of energy, the competition will be with (1) water power, (2) other mineral fuels. Water powers will here be only briefly considered.

There are many undeveloped water powers in the Pacific States and Alaska, and these could be made to furnish energy which might compete with that which could be obtained from Alaska coal. Eventually, however, recourse must be had to the mineral fuels, as the water powers are not sufficient to meet the demands of future industries. Therefore, the competing mineral fuels are probably the most important element in the problem of markets for the Alaska coal.

Examination of a map of North America showing distribution of coal indicates clearly that the Pacific seaboard of the continent is but poorly supplied with this mineral fuel. As distant land transportation of coal, especially over high divides, is always uneconomical and usually commercially impossible, it will be evident that Alaska coal fields are a natural source of fuel to supply the west coast population 
and industries. This is emphasized by considering the available tonnage. The states of Washington, Oregon, and California have an estimated aggregate of 22,000 million tons of coal reserves, to which should be added, say, 4,000 million tons for the coal of the British Columbia coast. The total of these is little more than a third of the coal supply of the Pacific slope of Alaska. There is known to be some coal in the Pacific drainage slope of Mexico, but this is probably not in sufficient amount materially to change these ratios. Evidently, therefore, Alaska is the only adequate source of supply of North American coal for the Pacific seaboard. The element of quality as affecting strength against competition is on the side of Alaska coal.

Coal Supplies in Foreign Countries.-Turning now to the coal supply of other lands bordering the Pacific. The South American countries have insufficient coal for their own use and are drawing: heavily on England. Australia is well supplied with coal, though most of it is not of high grade. Her mines are furnishing coal to South America and even to California. China's coal fields, though of enormous extent, are for the most part unavailable because of the lack of railways. When her teeming population turns to industries requiring fuel, the coal is likely to be needed at home. It is a significant fact, however, that a shipment of Chinese coals has recently been received at San Francisco. Japan, though an exporter of coal, has none to spare, as her reserves are small.

It is evident, therefore, that the lands which, from the standpoint of commerce are tied together by the Pacific, do not promise to become serious competitors with the Alaska coal. The opening of the Panama Canal will change the situation. Then the eastern coals-by water transportation only about six thousand statute miles to California, with an assured return cargo-can probably compete with the Alaska coal. This great engineering feat will change the boundaries of economic and geographic provinces. In considering the broad problems, however, it would appear unwise to ship coals from near the centers of population to the west coast at the expense of the fuel used, and any such movement can hardly persist under the operation of rational economic laws.

Alaska Coal vs. California OiL.-If Alaska is the natural source of fuel supply for the several million people of the western border of the continent, it is pertinent to inquire why the Territory does not furnish this fuel, but is drawing coal for its own use from other parts of the Pacific province at an economic loss. One reason for this lies in our unfortunate public land policy which $\mathrm{I}$ do not propose to discuss. The other is the growing production of fuel oil in California. The first has entirely prevented the development of the Alaska coal fields; the second has made the need of it less pressing. If 
oil fields had the same permanency as coal fields, the Alaska coal fields would have their greatest value at some distant time in the future. Experience in other fields has shown that the oil has only ephemeral importance in the industries and that it is only a matter of time when recourse must be had to coal. During the period of maximum production of an oil field, coal is often driven out of its natural market. For example, California oil is now used on steamers running to the Alaska ports which should be the coastal terminals of coal-hauling railways and is even carried three thousand miles to the Yukon, where it is used on river steamers which, by every economic consideration, should be using the abundant local supply of lignitic coal. Every effort should be made to check such evident economic loss. In time, of course, oil will increase in value, and will then only be used in near-by markets.

SUmmary.-The above considerations indicate that the coals of the Pacific slope of Alaska are geographically so located as to be the natural source of fuel for the western border of the continent. The supplying of this province with coals transported from long distances means the ignoring of the geographic factor and involves an economic loss. On the other hand, this is being rectified, and the present increasing demand of this province for mineral fuels is now being met by the petroleum of the California fields. The geologic conditions of the occurrence of petroleum are more favorable to exploitation than are those of coal. Geographically the California oil is favorably situated, and its physical character makes its transportation less affected by the geographic factor of distance than is coal. As a result, the abnormally rapid increase in output of California oil will soon prevent any considerable importations of coal from distant provinces and in this way prevent the economic losses to which attention has been directed.

The question naturally arises whether it is sound economics to save the Alaska coal at the expense of encouraging the abnormally rapid development of California oil, which is the more valuable fuel. It is not, however, proposed to discuss here the question either of the possibility or the justification for a governmental check on this oil production.

It is evident from the foregoing that there are two main sources of mineral fuel for the western border of the continent, namely, California oil and Alaska coal. The former is being drawn as rapidly as the means of development permit; the latter is undeveloped. Both geographic and geologic conditions favor the California oil. An ideal economic policy would be to draw on both sources of fuel for this geographic province, and not save one at the expense of the other. 